\title{
PROJ ECT MANAGEMENT MATURITY AND PROJ ECT MANAGEMENT SUCCESS IN THE ENGINEERING AND CONSTRUCTION INDUSTRIES IN SOUTHERN AFRICA ${ }^{\#}$
}

\author{
S. Pretorius ${ }^{1}$, H. Steyn ${ }^{2 *}$ \& J.C. J ordaan ${ }^{3}$ \\ Department of Engineering and Technology Management \\ Graduate School of Technology Management \\ University of Pretoria, South Africa \\ ${ }^{1}$ Suzaan.Pretorius@up.ac.za, ${ }^{2}$ Herman.Steyn@up.ac.za \\ ${ }^{3}$ Statomet \\ University of Pretoria, South Africa \\ Joyce.Jordaan@up.ac.za
}

\begin{abstract}
Previous studies have attempted to determine how the success of South African IT projects related to the project management maturity of the organisations that executed the projects. The study reported in this article was conducted during 2010 in the engineering and construction sectors. This paper reports on a structured questionnaire distributed to 1,625 individuals mainly in the South African engineering and construction industries, from which 255 responses were received. 'Project success' was self-defined by the respondents, who identified 'project success' within their unique environments and contexts. The bulk of the projects $(46 \%)$ were considered successful. The average perceived project management maturity level was 2.88 .
\end{abstract}

\section{OPSOMMING}

Vorige studies het bepaal hoe die sukses van Suid-Afrikaanse IT projekte vergelyk met die projekbestuursvolwassenheid van die organisasies wat die projekte uitgevoer het. Hierdie studie is uitgevoer gedurende 2010 in die ingenieurs- en konstruksiebedrywe. 'n Gestruktureerde vraelys is versprei aan 1,625 mense wat meestal werksaam was in die SuidAfrikaanse ingenieurswese- en konstruksiebedrywe, en 255 antwoorde is ontvang. 'Projeksukses' is selfgedefinieer deur die respondente op grond van hulle unieke omgewings en kontekste. Die grootste hoeveelheid van die projekte $(46 \%)$ is as suksesvol gereken. Die gemiddelde waargeneemde vlak van projekbestuursvolwassenheid was 2.88 .

\footnotetext{
* Corresponding author.

${ }^{1}$ The author was enrolled for the MSc (Project Management) degree at the Graduate School of Technology Management, University of Pretoria.

\# This article is an extended version of a paper presented at the 2011 ISEM conference
} 


\section{INTRODUCTION}

Studies to determine how the project management maturity of organisations related to the success of projects in the South African IT industry were conducted in 2003 and 2008 [1, 2]. This paper reports on part of a further study, performed during 2010, where it was decided also to include industries such as engineering, construction, petrochemicals, and mining to determine how the maturity of these industries differed from the maturity of the South African IT environment. The literature indicates that elsewhere in the world 'industries of origin' (engineering-based industries) can be expected to be more mature in terms of project management than industries that adapted project management principles and practices later on [3]. This study aimed to investigate the situation in Southern Africa.

The objectives for the study were the following:

i. To investigate the relationship between project management maturity and project success in engineering and construction industries in Southern Africa.

ii. To compare the 2010 level of maturity and the degree of success of engineering and construction industries with those of the IT industry in 2008.

iii. To investigate the effect of project size on project success in engineering and construction industries in Southern Africa.

iv. To investigate the effect of maturity in the nine knowledge areas on project outcome in the industries studied.

v. To explore the role of competencies of project managers in project success.

While the main focus of the study is to correlate success with maturity, project size and the competency of the project manager (rather than organisational maturity) might provide alternative explanations for project success, and these two aspects are therefore included in this study.

\section{LITERATURE REVIEW}

\subsection{Project management and maturity levels}

The Oxford Advanced Learner's Dictionary [4] defines 'maturity' as “the state of being fully grown or developed". When this concept is applied to a project, it could imply a situation where an organisation has standards and procedures in place that would assist it in reaching its objectives. An organisation is mature when it is in a position to deal perfectly with its projects [5].

Since the mid-1990s a number of project management maturity models (PMMMs) have been developed. Currently more than 30 models are available. The majority of these PMMMs consist of five distinct levels: level 1 is the initial level where no established project management practices exist; and level 5 is the 'optimising' level where the company is fully mature. Figure 1 describes the five maturity levels. However, at present there is still no single PMMM that is accepted worldwide $[6,7]$. 


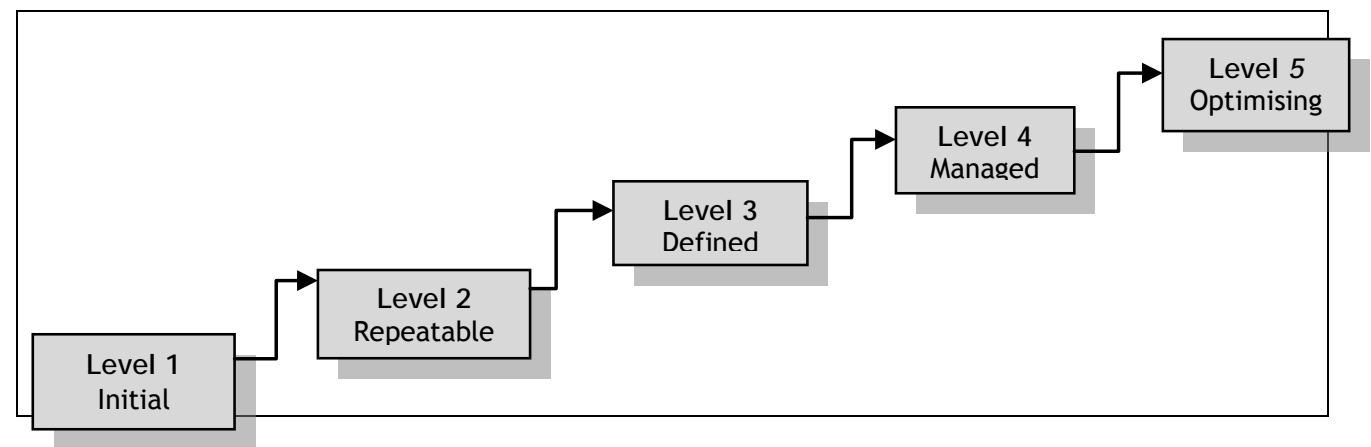

Figure 1: Project management maturity model [2]

\subsection{Project success}

The Oxford Advanced Learner's Dictionary [4] defines 'success' as "to achieve what was intended". It can thus be said that a project is successful when its goal has been achieved. There are several criteria, but they almost always include meeting requirements on time and within budget, as well as meeting quality requirements [8].

Project success is difficult to measure and to define, as it is dependent on a person's perception and perspective. Ika [6] is of the opinion that there is probably no such a thing as 'absolute success' in project management; there is only 'perceived success of a project', and how success is evaluated could change over time. The concept of success is ambiguous, inclusive, and multidimensional, and its definition is related to a specific context. Jugdev \& Müller [9] agree that success means different things to different people; the personal objectives of individuals lead them to judge the success of projects differently, and what one person perceives as a successful project can be a failure in another person's eyes.

According to Kendra \& Taplin [10], project management success is dependent on the following four dimensions:

- $\quad$ The skills and competencies of the project manager;

- Organisational structure;

- Measurement systems; and

- Management practices that represent an organisation's culture.

It can be concluded that project success is subjective, perceived, and difficult to measure. It is influenced by a variety of factors, including, but not limited to, formal project management practices, skills and competencies of the project manager and other team members, organisational culture, good communication, and support from senior management.

In this study project success was self-defined by the respondents, who identified project success within their unique environments and contexts.

\subsection{The influence of maturity on project outcome}

Mullaly \& Thomas [11] point out that there seems to be a relationship between maturity and performance, but that no statistically significant correlations exist to prove it. NietoRodriguez \& Evrard [12], from a consultancy firm, indicate that project failures are often the result of organisational aspects beyond the influence of the project manager; and they claim that a higher level of organisational maturity enhances project performance.

According to Nicholas et al. [8], a higher level of project management maturity does not necessarily guarantee project success. Labuschagne et al. [2] also found no significant correlation between project success and the maturity level of an ICT organisation in South Africa. This finding supports the notion that projects can be successful despite the maturity level of the organisation. 
Based on the above reports, there seems to be no consensus on whether a higher maturity level leads to project success or not.

\subsection{Maturity levels of organisations}

The majority of organisations are at the second level of the PMMMs, with almost all of the remaining organisations at the first or third level [13, 14]. Labuschagne et al. [2] found in their study of ICT organisations in South Africa that the highest number of organisations perceived themselves to be at level 3 , with the second most placing themselves at level 2 . Most organisations were perceived to be at maturity levels 1 to 3 , which supports the findings of Spundak et al. [13] and of Grant et al. [14].

Cooke-Davies and Arzymanow [3] researched the variation between different industries, and found that the petrochemical and defence industries were the most developed.

\subsection{Project size and project success}

Labuschagne et al. [2, 15] found that, in general, small projects in the IT environment in South Africa tended to fail more often than larger ones, due to the fact that formal project management processes are sometimes not followed on the smaller projects. Organisations tend to invest more effort in bigger projects, as their associated risks are higher. This is in line with the findings of Papke-Shields et al. [16], who found evidence that larger, more expensive projects had more at stake for the organisation, and therefore greater control was exercised in terms of time, cost, and integration, as well as formal quality and risk management practices.

\subsection{Project management knowledge areas}

The $\mathrm{PMBOK}^{\circledR}$ Guide [17] is probably the most popular of several available project management standards. It claims to be a summary of the collective knowledge within the profession of project management, and it is published and reviewed every four years by the Project Management Institute (PMI). It defines the following nine project management knowledge areas:

- $\quad$ scope management

- $\quad$ time management

- $\quad$ cost management

- quality management

- human relations management

- communications management

- $\quad$ risk management

- $\quad$ procurement management, and

- integration management.

Project success is often measured by the 'iron triangle' criteria of cost, quality, and time. The application of the nine knowledge areas is believed to have a major influence on achieving these criteria.

\section{HYPOTHESES}

In order to achieve the abovementioned objectives, the following 14 hypotheses were tested (where project management maturity and project success are perceived by the respondents):

$\mathrm{H}_{1}$ : Mature project management organisations produce more successful projects than less mature project management organisations.

$\mathrm{H}_{2}$ : $\quad$ Large projects are more successful than small projects. 
$\mathrm{H}_{3}$ : $\quad$ Project management organisations with mature project integration management practices produce more successful projects than project management organisations with less mature project integration management practices.

$\mathrm{H}_{4}$ : Project management organisations with mature scope management practices produce more successful projects than project management organisations with less mature scope management practices.

$\mathrm{H}_{1}$ : $\quad$ Project management organisations with mature time management practices produce more successful projects than project management organisations with less mature time management practices.

$\mathrm{H6}_{1}$ : Project management organisations with mature cost management practices produce more successful projects than project management organisations with less mature cost management practices.

$\mathrm{H}_{1}$ : Project management organisations with mature quality management practices produce more successful projects than project management organisations with less mature quality management practices.

$\mathrm{H} 8_{1}$ : Project management organisations with mature human resource management practices produce more successful projects than project management organisations with less mature human resource management practices.

$\mathrm{H} 9_{1}$ : Project management organisations with mature project communication management practices produce more successful projects than project management organisations with less mature project communication management practices.

$\mathrm{H} 10_{1}$ : Project management organisations with mature risk management practices produce more successful projects than project management organisations with less mature risk management practices.

$\mathrm{H}_{11}$ : $\quad$ Project management organisations with mature project procurement management practices produce more successful projects than project management organisations with less mature project procurement management practices.

$\mathrm{H} 12_{1}$ : Project management organisations with project managers with adequate competencies produce more successful projects than project management organisations with project managers with inadequate competencies.

$\mathrm{H}_{13} \mathrm{H}_{1}$ : The perceived level of maturity of the engineering and construction projects correlates positively with the perceived level of maturity of South African IT projects in 2008 as reported by Labuschagne et al. [2].

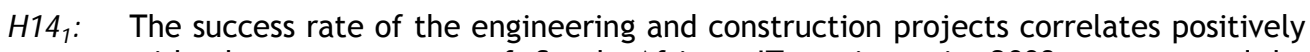
with the success rate of South African IT projects in 2008 as reported by Labuschagne et al. [2].

\section{RESEARCH METHODOLOGY}

In order to be able to compare results with previous studies [1, 2], a survey questionnaire developed by Sonnekus et al. [1] was used in this study. This questionnaire mapped the nine knowledge areas of the PMBOK ${ }^{\circledR}$ [17] on to a PMMM based on various maturity models. Respondents were asked to reflect on the outcomes of projects in their organisations, and to examine recent projects in terms of outcomes. The questionnaire consisted of 15 questions. It was hosted electronically, and invitations to participate were distributed via email. 
The invitation to complete the electronic survey was distributed to 1,625 individuals who had studied at the University of Pretoria; 255 responses were received. Thus $15.69 \%$ of those approached responded to the invitation to participate.

The data gathered were analysed with the help of SPSS, a statistical software package. In order to analyse the data, the following statistical tests were performed:

- Reliability analysis (Cronbach's Alpha).

- $\quad$ Descriptive statistics to describe the group profile.

- Hypothesis testing: Kruskal-Wallis tests, Mann-Whitney U tests, Chi-square, posthoc tests, t-tests, and p-values.

\section{RESULTS}

\subsection{Descriptive statistics}

Respondents who had studied at the University of Pretoria, and who came from South Africa and from some other African countries, participated in the survey. A total of 255 responses were received, and 273 projects were reported on. According to the respondents, the majority of projects were executed in South Africa (236), with the second-highest number of projects in Botswana (12). It should be noted that not all the responses were completed in full, and that some respondents did not complete certain sections of the questionnaire.

Respondents came mainly from the engineering and construction environment, as can be seen in Figure 2.

For the purposes of this study the three categories of project outcome were described in the questionnaire as follows:

- Failed: A project that is never completed or does not meet customer requirements. It delivers very little value or no value at all.

- Challenged: A project that is completed, but is late, over budget, or does not meet all the requirements. It delivers moderate value; less than what was anticipated.

- $\quad$ Successful: A project that is delivered on time, within budget, within scope, and complies with the quality requirements. It delivers strong value; the expected value.

The majority of projects (46\%) were perceived as successful, $36 \%$ as challenged, and the minority $(18 \%)$ as failures.

The majority of respondents $(31.9 \%)$ perceived their organisation's project management maturity, on average, at level 3 , with $27.6 \%$ at level 2 . Most organisations $(71.3 \%$ ) are perceived to be at maturity levels 1 to 3 . The average perceived maturity is 2.88 . Labuschagne et al. [2] found that the average perceived maturity of South African IT organisations was 2.97 . 


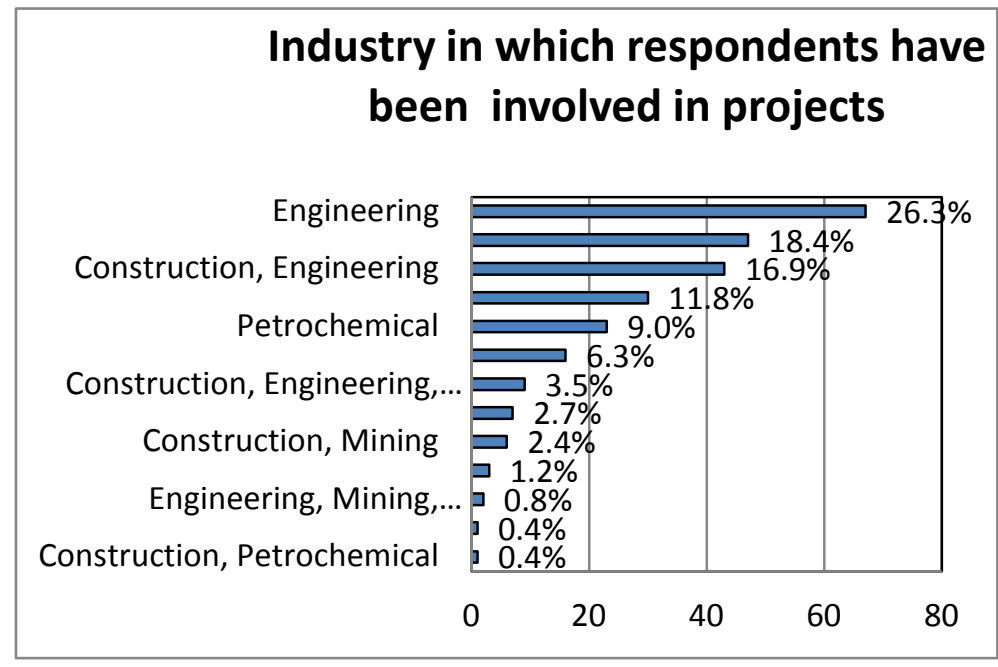

Figure 2: Industries in which respondents have been involved in projects

\subsection{Hypothesis testing}

Because parts of the study consisted of small subgroups, it was decided to use nonparametric tests for hypotheses 1 to 12 . As adequate data were available for hypotheses 13 and 14 , they were tested by parametric statistics.

\subsubsection{Testing of hypotheses 3 to 11}

The scores of the sub-questions in the questionnaire pertaining to hypotheses 3 to 11 were added together for each respondent, after which the average score was calculated for each question. The averages of the respondents were then grouped into five categories for each question. 'Not applicable' was treated as 'missing'. The grouping was done as outlined in Table 1.

Table 1: Categories for questions

\begin{tabular}{|c|c|}
\hline Average & Category \\
\hline $1.00-1.49$ & Level 1 \\
\hline $1.50-2.49$ & Level 2 \\
\hline $2.50-3.49$ & Level 3 \\
\hline $3.50-4.49$ & Level 4 \\
\hline $4.50-5.00$ & Level 5 \\
\hline
\end{tabular}

If the Kruskal-Wallis Test indicated that there were significant differences in the mean percentages of successful projects, the Mann-Whitney $U$ Test was used to perform multiple comparisons (pare-wise comparisons). It was decided beforehand to test for differences across levels $1-4,1-5,2-4,2-5$ and $3-5$; hence the level of $a=0.05$ was adjusted to $a=0.01$ $\left(\alpha=\frac{0.05}{5}\right)$.

\subsubsection{Reliability testing}

A Cronbach Alpha of 0.7 or higher indicates that respondents have answered the items in a consistent way, and it is thus an indicator of reliability. Table 2 indicates that all the questions in the questionnaire pertaining to the nine knowledge areas have a good reliability.

Table 3 outlines the results and interpretations of the hypotheses testing, as well as the statistical measures that were used. The statistical measures and tests used in the study are described elsewhere. 
Table 2: Cronbach's Alpha test for the knowledge areas

\begin{tabular}{|cl|c|c|}
\hline \multicolumn{1}{|c|}{ Knowledge area } & Cronbach's Alpha & N of items \\
\hline 1. & Project integration management & 0.931 & 7 \\
\hline 2. & Project scope management & 0.947 & 8 \\
\hline 3. & Project time management & 0.954 & 8 \\
\hline 4. $\quad$ Project cost management & 0.928 & 3 \\
\hline 5. & Project quality management & 0.952 & 3 \\
\hline 6. $\quad$ Project HR management & 0.922 & 7 \\
\hline 7. $\quad$ Project communications management & 0.947 & 8 \\
\hline 8. & Project risk management & 0.975 & 11 \\
\hline 9. Project procurement management & 0.948 & 7 \\
\hline
\end{tabular}

Table 3: Results of statistical hypothesis testing

\begin{tabular}{|c|c|c|c|}
\hline $\begin{array}{l}\text { Null } \\
\text { hypo- } \\
\text { thesis }\end{array}$ & $\begin{array}{l}\text { Statistical } \\
\text { Measures } \\
\text { Used }\end{array}$ & Result & Interpretation \\
\hline $\mathrm{H} 1_{0}$ & $\begin{array}{l}\text { Kuskal-Wallis } \\
\text { Test }\end{array}$ & Accepted & $\begin{array}{l}\text { There is no relationship between the maturity of } \\
\text { the sample of project management organisations } \\
\text { and the outcome of the projects that they } \\
\text { produce. }\end{array}$ \\
\hline $\mathrm{H} 2_{0}$ & $\begin{array}{l}\text { - Kuskal-Wallis } \\
\text { Test }\end{array}$ & Accepted & $\begin{array}{l}\text { No relationship between the size of a project } \\
\text { and its outcome was found in this study. }\end{array}$ \\
\hline $\mathrm{H} 3_{0}$ & $\begin{array}{l}\text { - Kuskal-Wallis } \\
\text { Test } \\
\text { - Mann-Whitney } \\
\text { Test }\end{array}$ & Rejected & $\begin{array}{l}\text { The sample of project management organisations } \\
\text { with mature integration management practices } \\
\text { produces more successful projects than those } \\
\text { organisations with less mature integration } \\
\text { management practices. }\end{array}$ \\
\hline $\mathrm{H} 4_{0}$ & $\begin{array}{l}\text { - Kuskal-Wallis } \\
\text { Test } \\
\text { - Mann-Whitney } \\
\text { Test }\end{array}$ & Rejected & $\begin{array}{l}\text { The sample of project management } \\
\text { organisations with mature scope management } \\
\text { practices produces more successful projects } \\
\text { than those organisations with less mature scope } \\
\text { management practices. }\end{array}$ \\
\hline $\mathrm{H} 5_{0}$ & $\begin{array}{l}\text { - Kuskal-Wallis } \\
\text { Test } \\
\text { - Mann-Whitney } \\
\text { Test }\end{array}$ & Rejected & $\begin{array}{l}\text { The sample of project management organisations } \\
\text { with mature time management practices } \\
\text { produces more successful projects than those } \\
\text { organisations with less mature time management } \\
\text { practices. }\end{array}$ \\
\hline $\mathrm{H} 6_{0}$ & $\begin{array}{l}\text { - Kuskal-Wallis } \\
\text { Test } \\
\text { - Mann-Whitney } \\
\text { Test }\end{array}$ & Rejected & $\begin{array}{l}\text { The sample of project management organisations } \\
\text { with mature cost management practices } \\
\text { produces more successful projects than those } \\
\text { organisations with less mature cost management } \\
\text { practices. }\end{array}$ \\
\hline $\mathrm{H} 7_{0}$ & $\begin{array}{l}\text { Kuskal-Wallis } \\
\text { Test }\end{array}$ & Accepted & $\begin{array}{l}\text { There is no relationship between the maturity of } \\
\text { quality management practices of the sample of } \\
\text { project management organisations and the } \\
\text { outcome of the projects that they produce. }\end{array}$ \\
\hline $\mathrm{H} 8_{0}$ & $\begin{array}{l}\text { - Kuskal-Wallis } \\
\text { Test } \\
\text { - Mann-Whitney } \\
\text { Test }\end{array}$ & Rejected & $\begin{array}{l}\text { The sample of project management } \\
\text { organisations with mature human resource } \\
\text { management practices produces more successful } \\
\text { projects than other organisations with less } \\
\text { mature human resource management practices. }\end{array}$ \\
\hline $\mathrm{H} 9_{0}$ & $\begin{array}{l}\text { - Kuskal-Wallis } \\
\text { Test }\end{array}$ & Accepted & $\begin{array}{l}\text { There is no relationship between the maturity of } \\
\text { project communication management practices } \\
\text { of the sample of project management } \\
\text { organisations and the outcome of the projects } \\
\text { that they produce. }\end{array}$ \\
\hline
\end{tabular}




\begin{tabular}{|c|c|c|c|}
\hline $\begin{array}{l}\text { Null } \\
\text { Hypo- } \\
\text { thesis }\end{array}$ & $\begin{array}{l}\text { Statistical } \\
\text { Measures } \\
\text { Used }\end{array}$ & Result & Interpretation \\
\hline $\mathrm{H} 10_{0}$ & $\begin{array}{l}\text { - Kuskal-Wallis } \\
\text { Test }\end{array}$ & Accepted & $\begin{array}{l}\text { There is no relationship between the maturity of } \\
\text { project risk management practices of the sample } \\
\text { of project management organisations and the } \\
\text { outcome of the projects that they produce. }\end{array}$ \\
\hline $\mathrm{H} 11_{0}$ & $\begin{array}{l}\text { - Kuskal-Wallis } \\
\text { Test }\end{array}$ & Accepted & $\begin{array}{l}\text { There is no relationship between the maturity of } \\
\text { project procurement management practices of } \\
\text { the sample project management organisations } \\
\text { and the outcome of the projects that they } \\
\text { produce. }\end{array}$ \\
\hline $\mathrm{H} 12_{0}$ & $\begin{array}{l}\text { - Kuskal-Wallis } \\
\text { Test }\end{array}$ & Accepted & $\begin{array}{l}\text { There is no relationship between the sample of } \\
\text { project management organisations with project } \\
\text { managers with adequate competencies and the } \\
\text { outcome of the projects that they produce. }\end{array}$ \\
\hline $\mathrm{H} 13_{0}$ & $\begin{array}{l}\text { - Tests of } \\
\text { normality } \\
\text { - Levene's Test for } \\
\text { equality of } \\
\text { variances } \\
\text { - t-test for } \\
\text { equality of } \\
\text { means }\end{array}$ & Accepted & $\begin{array}{l}\text { There is no significant difference between } \\
\text { perceived maturity of engineering and } \\
\text { construction projects and the perceived } \\
\text { maturity of South African IT projects as reported } \\
\text { on in the } 2008 \text { Prosperus Report [2]. }\end{array}$ \\
\hline $\mathrm{H} 14_{0}$ & $\begin{array}{l}\text { - Tests of } \\
\text { normality } \\
\text { - Levene's Test for } \\
\text { equality of } \\
\text { variances } \\
\text { - t-test for } \\
\text { equality of } \\
\text { means }\end{array}$ & Rejected & $\begin{array}{l}\text { The success rate of engineering and construction } \\
\text { projects in the sample differs significantly from } \\
\text { the success rate of South African IT projects as } \\
\text { reported on in the } 2008 \text { Prosperus Report [2]. }\end{array}$ \\
\hline
\end{tabular}

\section{CONCLUSION AND RECOMMENDATION}

\subsection{Outcome of African engineering and construction projects and the perceived level of maturity of organisations}

The majority of projects were perceived by the respondents as successful and the minority as failures.

Project management organisations had an average perceived level of maturity of 2.88 , and the majority of organisations were at level 3. Most organisations were perceived to be at maturity levels one to three, which supports the findings in other environments, e.g. those of Spundak et al. [13], Pretorius et al. [18, 19], Labuschagne et al. [20], and Grant et al. [14].

\subsection{The relationship between project management maturity and project outcome}

The study failed to establish any correlation between the project management maturity of an organisation and the perceived outcome of the projects that it produces. This finding is in line with Nicholas et al. [8], Pretorius et al. [19], and Labuschagne et al. [2]. They all claim that higher project management maturity does not automatically lead to project success; projects can be successful despite the maturity level of the organisation.

This finding could be an indication that project success is dependent on factors other than standardised practices implemented by the project office. The factors that could influence project success might include:

- Organisational culture [21]

- The competence level of the least competent project team member [22]

- The size of the project [16], and 
- The competence of the project manager [9].

Additional empirical testing is necessary to gain more knowledge about the connections between project success and the above factors.

\subsection{The relationship between project size and project outcome}

The hypothesis testing failed to find a correlation between the size of a project and its perceived outcome. This is contrary to the findings of Papke-Shields et al. [16], Pretorius et al. [19], and Labuschagne et al. [2]; they all found that bigger projects tend to be more successful.

It therefore seems that the situation pertaining to the engineering and built environment projects investigated in this study differs from project management in the USA as well as from the ITC industry in South Africa. A possible explanation for this phenomenon could be the fact that African engineering and construction organisations invest more appropriate efforts, funds, and external resources in both small and large projects. Another explanation could be that large construction projects in Africa experience unique challenges that make it difficult for smaller ones to achieve better results.

\subsection{The impact of the application of the nine PMBOK $^{\circledR}$ knowledge areas to project outcome}

It was found that the following $\mathrm{PMBOK}^{\circledR}$ [17] knowledge areas correlate positively with project outcome:

- Integration management $\left(\mathrm{H} 3_{1}\right)$

- Scope management $\left(\mathrm{H}_{4}\right)$

- Time management $\left(\mathrm{H} 5_{1}\right)$

- Cost management $\left(\mathrm{H}_{1}\right)$

- Human resource management $\left(\mathrm{H}_{1}\right)$

The hypothesis testing indicated no significant correlation between the following PMBOK ${ }^{\circledR}$ [17] knowledge areas and project outcome:

- Quality management $\left(\mathrm{H}_{0}\right)$

- Communication management $\left(\mathrm{H}_{0}\right)$

- Risk management $\left(\mathrm{H} 10_{0}\right)$

- Procurement management $\left(\mathrm{H} 11_{0}\right)$

Scope-, time-, cost- and quality management are 'core functions', while human relations, communications, and risk and procurement management are 'facilitating functions' according to $\mathrm{PMBOK}^{\circledR}[17]$. In this study the majority of knowledge areas that were found to have a direct relationship with project outcome were 'core functions', and the bulk of areas that had no significant correlation with project outcome were 'facilitating functions'. The only exceptions are human resource management (a facilitating function where maturity correlates with project outcome) and quality management (a core function that was found not to correlate with project outcome). Respondents probably realise the important role of aspects such as leadership and teamwork, which are often mentioned in the literature as being essential for project success.

According to Watson \& Korukonda [23], "as quality management becomes embedded in more and more organisations, it has come to mean different things to different people". In the industries that were studied in this report, it could be that, due to the nature of the projects, quality management principles and measures have been so entrenched in the company's work ethos and standard operating procedures, that project managers do not even realise that they are applying them in their projects. This might have led to bias regarding this knowledge area. 
Not all projects require significant procurement work. This might also have led to bias in the responses regarding procurement management.

\subsection{The influence of the competency of project managers on the outcome of projects}

The study found no relationship between the competency of project managers and the outcome of projects. This supports the notion of Kendra et al. [10] that project management success is dependent on four dimensions, of which the skills and competencies of the project manager are only one.

\subsection{Maturity in the engineering and construction sector versus maturity in the IT sector}

No difference between the average perceived maturity levels of companies in the South African IT environment in 2008 and the engineering and construction sector were found in the study; the engineering and construction industry compared favourably with the IT industry in terms of overall maturity level.

Cooke-Davies et al. [3] found that 'industries of origin' are more mature in project management than industries that adopted the discipline more recently. Construction and engineering can be considered industries of origin, and therefore higher maturity could have been expected in these sectors than in the IT sector.

In this study no difference could be found in the maturity levels of the two industries. This could be due to the fact that Labuschagne et al. [2] did their research in South Africa, whereas this study on the engineering and construction sectors was conducted in South Africa and in other parts of Africa. Project management companies in the rest of Africa are generally less experienced than South African project management companies.

\subsection{Success rate in the engineering and built environment sector compared to projects in the IT sector}

The study found a significant difference between the average percentage of completed projects that were successful in the South African IT sector and the African engineering and construction industry. The IT industry had a higher percentage of successful projects in 2008.

A possible explanation for this could be that Labuschagne et al. [2] researched only South African IT companies, whereas this study had respondents from South Africa and from other parts of Africa. South African project companies tend to be more experienced and therefore more successful in their execution of projects. Failure is also more obvious in engineering and construction projects than in IT projects.

\subsection{Recommendations}

Further research is necessary in order to determine why risk management had no influence on the outcome of engineering and construction projects in this study. According to Royer [24], "unmanaged or unmitigated risks are one of the primary causes of project failure". Thompson and Perry [25] say that if risk management is not exercised, the result is poor performance with increased cost and time delays. This particular finding of the study thus seems to contradict conventional wisdom.

\subsection{Shortcomings of the study}

The questionnaire consisted of 15 questions, and the nature of some questions was very repetitive. Respondents normally do not have much time to spend on long questionnaires; and this might have led to some respondents completing only some of the questions.

The respondents identified project success from their unique environments and contexts. It could be argued that the customer's perspective of the outcome of the project should also be taken into account to provide a more objective picture of the real situation. Due to the fact that an existing questionnaire was used, this was not possible for this study. This should, however, be addressed in future studies. 


\section{REFERENCES}

[1] Sonnekus, R. \& Labuschagne, L. 2003. The Prosperus Report 2003: ICT project management maturity versus project success in South Africa. Johannesburg, Rand Afrikaans University.

[2] Labuschagne, L. \& Marnewick, C. 2009. The Prosperus Report 2008. IT Project Management Maturity vs. Project Success in South Africa. Project Management South Africa, South Africa.

[3] Cooke-Davies, T.J . \& Arzymanow, A. 2003. The maturity of project management in different industries: An investigation into variations between project management models. International J ournal of Project Management, 21, pp 471-478.

[4] Oxford Advanced Learner's Dictionary of Current English. 2001. $6^{\text {th }}$ ed. Oxford: University Press.

[5] Andersen, S.A. \& J essen, S.A. 2002. Project maturity in organisations. International J ournal of Project Management, 21, pp 457-461.

[6] Ika, L.A. 2009. Project success as a topic in project management journals. Project Management J ournal, 40(4), pp 6-19.

[7] Organizational Project Management Maturity Models, http://www.acis.org.co [accessed 10/12/10].

[8] Nicholas, J.M. \& Steyn, H. 2008. Project management for business engineering, and technology. Principles and practice. $3^{\text {rd }}$ ed. Burlington: Butterworth-Heinemann.

[9] Jugdev, K. \& Müller, R. 2005. A retrospective look at our evolving understanding of project success. Project Management J ournal, 36(4), pp 19-31.

[10] Kendra, K. \& Taplin, L.J . 2004. Project success: A cultural framework. Project Management J ournal, 35(1), pp 30-45.

[11] Mullaly, M.E.M. \& Thomas, J . 2010. Re-thinking project management maturity. Perspectives gained for explorations of fit and value. Project Management Institute Inc.

[12] Nieto-Rodriguez, A. \& Evrard, D. 2004. Boosting business performance through programme and project management. A first goal survey on the current state of project management maturity in organisations across the world. PriceWaterhouseCoopers.

[13] Spundak, M. \& Striga, K. 2010. Project management maturity of Croatian companies: Is there any? Project Management Institute Inc.

[14] Grant, K.P. \& Pennypacker, J.S. 2006. Project management maturity: An assessment of project management capabilities among and between selected industries. IEEE Transactions on Engineering Management, 53(1), pp 59-68.

[15] Labuschagne, L., Marnewick, C. \& J akovljevic, M. 2008. IT Project Management Maturity: A South African Perspective. Proceedings of the PMSA Conference 2008: From Strategy to Reality, Midrand, South Africa.

[16] Papke-Shields., K.E., Beise, C. \& Quan, J. 2010. Do project managers practice what they preach, and does it matter to project success? International J ournal of Project Management, 28, pp 650-662.

[17] Project Management Institute, Inc. 2008. A guide to the project management body of knowledge (PMBOK ${ }^{\circledR}$ Guide). Newtown Square, Pennsylvania, USA.

[18] Pretorius, S. 2011. Project management maturity versus project management success in the engineering and built environment: An African perspective. Dissertation in partial fulfilment of the requirements for Masters in Project Management, University of Pretoria.

[19] Pretorius, S., Steyn, H. \& J ordaan, J .C. 2011. Project management maturity versus project management success in the engineering and built environment: An African perspective. Industrial Engineering, Systems Engineering and Engineering Management (ISEM) Conference, Stellenbosch, South Africa.

[20] Labuschagne, L. et al. 2012. Project management maturity for project success in South Africa 2010. PMSA. In press.

[21] Yazici, H.J . 2010. Role of project maturity and organizational culture on project success. PMI Research Education Conference, Washington, D.C.

[22] Berger, M.E. 2010. Contribution of Individual Project Participant Competencies to Project Success. Project Management Institute Inc.

[23] Watson, J. \& Karukonda, A. 1995. The TQM jungle: A dialectical analysis. International J ournal of Quality and Reliability Management, 12(9), pp 100-109.

[24] Royer, P.S. 2000. The undiscovered dimension of project management. PM Network, 14, pp 3140.

[25] Thompson, P.A \& Perry, J.G. 1992. Engineering construction risks: A guide to project risk analysis and risk management. London: Thomas Telford. 